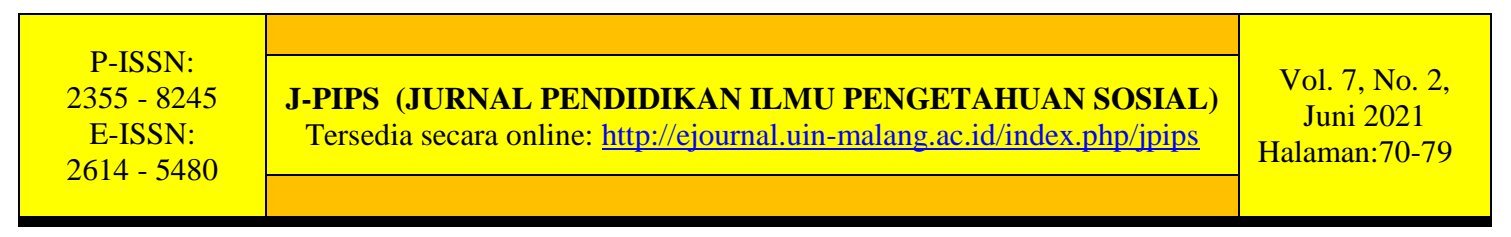

\title{
Implementasi Silent Demonstration pada Open Learning Environments (OLEs) Sebagai Penguatan Keterampilan 4C
}

\author{
Diah Ambarumi Munawaroh \\ MTs Negeri Kota Batu, Jl. Pronoyudo No. 4 Areng-areng, Batu, Jawa Timur, \\ Indonesia \\ bundajeki@gmail.com
}

Diterima: 17-02-2021.; Direvisi: 12-06-2021; Disetujui: 16-06-2021

Permalink/DOI: 10.15548/jpips.v7i2.11680

\begin{abstract}
Abstrak : Tujuan penelitian ini yaitu untuk mendeskripsikan implementasi Silent Demonstration pada Open Learning Environments dan bagaimana kegiatan tersebut dapat mengintegrasikan siswa untuk berfikir kritis, kreatif, komunikatif, kolaboratif mata pelajaran IPS. Metode yang digunakan peneliti pendekatan kualitatif fenomenologis dengan mendeskripsikan tingkah laku, tanggapan, tindakan individu dan kelompok dalam bentuk kata-kata dan bahasa, secara alamiah (natural). Teknik pengumpulan data melalui observasi pada kelas VIII G dan VIII H, wawancara mendalam pada guru mata pelajaran dan ketua kelompok sejumlah 14 siswa dan dokumentasi selama penelitian berlangsung. Hasil penelitian adalah Implementasi silent demonstration pada OLEs menarik perhatian siswa melalui pengamatan dalam memahami kegiatan produksi, konsumsi dan distribusi sehingga tujuan pembelajaran tercapai. Kegiatan pembelajaran ini mengintegrasikan keterampilan terpadu antara Silent Demonstration yang menarik perhatian siswa melalui pengamatan dan Open Learning Environtments (OLEs) yang menyajikan konteks perspektif sumber daya alam dari lingkungan untuk membangun berbagai sudut pandang melalui alat/media sebagai upaya menguatkan pembelajaran 4C (berpikir kritis, kreatif, kolaboratif dan komunikatif).
\end{abstract}

\section{Kata Kunci: Silent Demonstration; Open Learning Environments (OLEs); Keterampilan 4C}

\section{Implementation of Silent Demonstration in Open Learning Environments (OLEs) as Reinforcement 4C Skills}

\begin{abstract}
The purpose of this study is to describe the implementation of Silent Demonstration in Open Learning Environments and how these activities can integrate students to critical thinking, creative, communication, and collaboration in social studies subjects. The method used by the researcher is a phenomenological qualitative approach by describing the behavior, responses, actions of individuals and groups in the form of words and language, naturally (naturally). Data collection techniques
\end{abstract}


through observations in grades VIII $G$ and VIII H, in-depth interviews with subject teachers and group leaders of 14 students and documentation during the research. The research results are that the implementation of silent demonstrations in OLEs attracts students' attention through observations in understanding production, consumption and distribution activities so that learning objectives are achieved. This learning activity integrates integrated skills between Silent Demonstration which attracts students' attention through observation and Open Learning Environments (OLEs) which presents the context of a natural resource perspective from the environment.to build multiple points of view through tools/media as an effort to strengthen $4 C$ learning (critical thinking, creative, collaborative and communicative)

\section{Keywords: Silent Demonstration; Open Learning Environtments (OLEs); Skills 4C}

\section{PENDAHULUAN}

Kemajuan inovasi teknologi revolusi industri 4.0 mengawali transformasi dalam segala aspek sendi kehidupan, salah satunya perubahan paradigma pendidikan. Peserta didik abad 21 diharapkan memiliki keterampilan untuk meningkatkan kompetensinya dan bersaing dalam berbagai bidang kehidupan. Keterampilan tersebut adalah Critical Thinking, Communication, Creative Thinking, dan Collaboration (Zubaidah, 2018). Howard Gardner menyatakan saat ini anak-anak harus dilengkapi pengetahuan, berpikir kritis dan keterampilan yang tidak dapat dilakukan oleh mesin (Akgunduz, 2015). Abad 21 Keterampilan 4C sangat dibutuhkan dan dapat dilatihkan melalui pembelajaran pada lembaga pendidikan di Indonesia. Model pembelajaran selama ini memiliki potensi yang baik untuk mengembangkan keterampilan 4C dengan memahami model pendekatan pembelajaran tersebut dan mengembangkan indikator yang sesuai dengan 4C, serta melakukan tindak reflektif yang kontinyu melalui PTK (Asari et al., 2015). Zul Hidayatullah dkk melakukan analisis pada 300 artikel jurnal nasional dan internasional berkaitan dengan keterampilan $4 \mathrm{C}$, ditemukan berpikir kritis menjadi topik yang paling banyak diteliti dengan persentase $12 \%$ dan $27 \%$ dan pembelajaran berbasis keterampilan 4C menggunakan sampel yang relatif kecil yaitu di bawah 100 dengan mayoritas lokasi penelitian terfokus di Bali-Nusra dan Jawa (Hidayatullah et al., 2021).

Metode silent demonstration berkaitan dengan prinsip open learning environments (OLEs) yaitu meningkatkan cara berpikir multiple perspektif, mendorong belajar mandiri, memberikan siswa pengalaman langsung dan konkret dalam dunia nyata, menjembatani antara pengalaman pribadi dan teori yang bersifat personal, memberikan alat dan sumber untuk membantu siswa dalam belajar (Charles M.Reigeluth Alison A.Carr-Chellman, 1389). Lingkungan belajar terbuka bertujuan untuk mendorong siswa berpikir kritis, berorientasi pada inquiry-oriented dan heuristic-based learning, menyumbangkan perspektif yang berbeda-beda pada pemecahan masalah yang dikembangkan secara mandiri tanpa arahan dan tidak terstruktur, kegiatan ini sepadan dengan keterampilan 4C (kritis, kreatif, komunikasi, dan kolaborasi). Try Nersia Nurhemi menemukan Active Learning dengan Silent Demonstration mampu menumbuhkan kemampuan keterampilan dan hasil belajar sains siswa (Nurhemy et al., 2011). Penelitian Melviana Gulo dan Losten Tamba menghasilkan silent demonstration berdampak bermakna pada kecakapan penulisan teks prosedur siswa (Gulo \& Tamba, 2019). Penelitian Tarigan Silvia dan Aprilia Isti menghasilkan metode silent demonstration memiliki pengaruh pada kemampuan memperagakan teks prosedur siswa (Herawati, 2016). Pembelajaran IPS memiliki peranan penting dalam menghasilkan siswa berkualitas yang peka pada lingkungan, imajinatif, 
analitis serta mampu bertindak di masyarakat. Belajar merupakan kegiatan yang menghasilkan perubahan perilaku yang terbangun dari siswa sendiri karena mengalami dan melewati proses sendiri.

Metode silent demonstration sudah diterapkan oleh guru pengajar mata pelajaran IPS kelas VIII MTsN Batu pada materi kegiatan produksi, konsumsi dan distribusi. Berdasarkan observasi awal pada tanggal 5 maret 2018, Anis Maisaroh, M.Pd sebagai guru mata pelajaran IPS kelas VIII mengatakan metode tersebut menarik perhatian siswa karena guru memperagakan langkah-langkah dan prosedur bisu sehingga mendorong siswa melakukan pengamatan secara mental serta menemukan jawaban dengan mengkonstruksi pemikirannya. Tujuan penelitian ini berdasarkan observasi awal untuk menggambarkan penerapan metode Silent Demonstration pada Open Learning Environtments dan bagaimana kegiatan pembelajaran tersebut dapat mengintegrasikan dan memberikan ruang bagi siswa untuk berfikir kritis, kreatif, kolaboratif dan komunikatif mata pelajaran IPS kelas VIII G dan VIII H MTsN Kota Batu pada tema kegiatan Produksi, Konsumsi dan Distribusi.

\section{METODE}

Pendekatan penelitian kualitatif adalah penelitian yang bersifat alamiah berorientasi naturalistic, mendasar dengan terjun langsung ke lapangan (Nazir, 1988). Jenis penelitian kualitatif memahami fenomena yang dialami subyek penelitian seperti tingkah laku, anggapan, secara holistic dengan cara deskripsi dalam bentuk kata-kata dan bahasa, dengan memanfaatkan berbagai metode alamiah (Moleong, 2019).

Penelitian ini mengeksplorasi dengan membaca fenomena sosial antara lain pelaksana, peristiwa, lokasi dan waktu. Latar digambarkan untuk mengembangkan pertanyaan dasar: apa, bagaimana kejadian itu terjadi; siapa yang terlibat; kapan terjadinya; dimana kejadiannya (Ghony, 2012). Ditinjau dari segi tempat dilakukannya penelitian termasuk penelitian lapangan yaitu menyelami kondisi, proses berlangsung, interaksi individu dan kelompok serta mengungkap keunikan yang terdapat dalam lingkungan tertentu.

Penelitian ini dilakukan pada MTsN Kota Batu Provinsi Jawa Timur Indonesia. Teknik pengumpulan data menggunakan observasi pada 2 kelas yaitu VIII G dan VIII H pada tanggal 15 maret 2018 yaitu kelas yang mendapatkan materi kegiatan produksikonsumsi-distribusi. Wawancara mendalam pada guru mata pelajaran IPS kelas VIII G dan VIII H serta ketua kelompok sebanyak 14 siswa yang dilakukan tanggal 15-17 maret 2018 dengan durasi 20 menit setiap orang. Pengambilan wawancara, observasi dan dokumentasi selama penelitian berlangsung. Teknik analisis data dengan transkrip wawancara, mensintesis data dengan melakukan pengkodean. Creswell menjelaskan data penelitian kualitatif dianalisis dengan merencanakan dan mengelompokkan teks data, selanjutnya melakukan reduksi data dan penyajian data (Creswell, 2015). Proses pengambilan data untuk penelitian ini dilakukan pada tanggal 5 - 17 maret 2018.

\section{HASIL DAN PEMBAHASAN \\ Hasil}

\section{Implementasi Silent Demonstration pada OLEs Materi Produksi-Konsumsi-Sub}

Observasi dilaksanakan hari kamis tanggal 15 maret 2018 kelas VIII G jam pelajaran ke III dan IV pukul (08.15-09.45) dilanjutkan jam pelajaran ke V dan VI di kelas VIII H pukul (10.15-11.00). Guru mengucapkan salam, menanyakan kabar, mengabsen kehadiran siswa, kemudian menjelaskan tujuan pembelajaran diharapkan siswa mampu 
memahami kegiatan produksi, konsumsi, dan distribusi. Guru membentuk kelompok masing-masing 5 siswa sejumlah 7 kelompok kemudian menunjuk 3 siswa membantu guru sebagai model dengan berperan sebagai sales, penjaga toko, dan pembeli. Guru meminta siswa di kelas untuk memperhatikan silent demonstration, dan meminta mencatatkan kegiatan pada lembar kerja yang sudah dibagikan. Hasil dokumentasi kegiatan pembelajaran menggunakan metode Silent Demonstration pada Gambar 1.

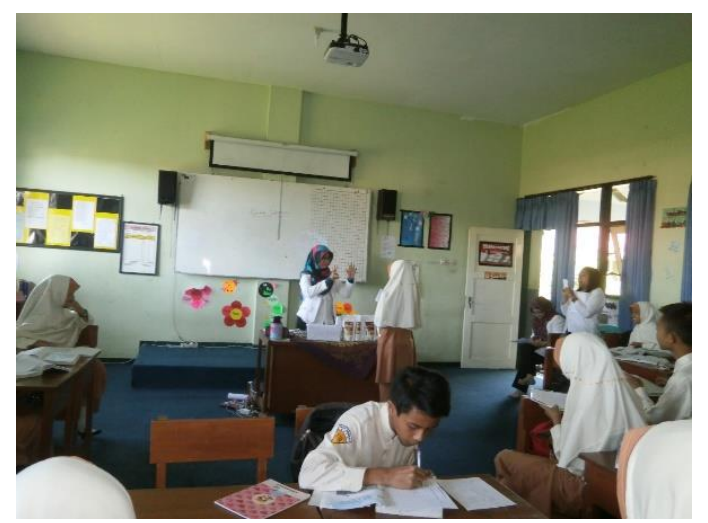

Gambar 1. Kegiatan Pembelajaran Menggunakan Metode Silent Demonstration

Gambar 1. menunjukkan guru telah memulai melakukan silent demonstrasi dengan mengiris buah apel kemudian, memasukkan dalam kardus yang diberikan keterangan mesin produksi, beberapa detik kemudian guru mengambil kripik apel yang sudah diletakkan dalam kardus sebelumnya dan menunjukkan pada siswa bahwa buah apel sudah diproses menjadi keripik apel. Selanjutnya guru melakukan pengemasan label dan memasukkan dalam kemasan hingga produk siap dijual. Salah satu siswa yang berperan sebagai sales mendatangi guru, menanyakan harga dan meminta kerjasama untuk memasarkan keripik apel. Siswa berperan sebagai sales mendatangi toko membuat kesepakatan menitipkan keripik apel, kemudian siswa berperan sebagai pembeli mendatangi penjaga toko membeli keripik apel kemudian membuka bungkus dan memakannya. Peneliti tertarik pada tingkah siswa di kelas saat silent demonstrasi, khususnya saat pembeli beraksi memakan keripik apel, seluruh siswa tertawa dan mengucapkan kata-kata lucu, artinya kegiatan tersebut mampu menarik perhatian siswa dan mengikuti pembelajaran dengan menyenangkan.

Silent demonstrasi telah selesai dilakukan kemudian, guru menanyakan apakah siswa ada yang belum paham? dan hampir seluruh siswa mengatakan sudah paham, kemudian guru meminta siswa menuliskan hasil pengamatan pada lembar kerja. Guru meminta sebagian siswa memaparkan hasil pengamatan, siswa pertama NR mengatakan bahwa guru sedang mengiris apel untuk diolah sebagai keripik apel, guru mengolah bahan mentah menjadi barang memiliki nilai guna/manfaat, artinya guru melakukan proses produksi. Siswa kedua AD menjelaskan bahwa siswa yang ditunjuk sebagai sales melakukan kegiatan distribusi karena menyalurkan keripik apel dari guru dititipkan pada pemilik toko. Siswa ketiga IP menyatakan bahwa temannya sebagai pembeli kemudian memakan kripik tersebut adalah konsumen, karena melakukan kegiatan konsumsi.

Keterampilan siswa berpikir kritis (Critical Thinking Skills)

Kegiatan silent demonstration jika sudah selesai maka, guru memberikan tantangan dengan membagikan gambar buah yang berbeda pada setiap kelompok serta meminta 
siswa berimajinasi dan mendiskusikan: apabila siswa memiliki bahan mentah buah dalam jumlah yang berlimpah maka; 1) buah tersebut akan diproduksi menjadi apa, 2) siapa yang akan mengkonsumsi, 3) bagaimana alur pendistribusiannya dan 4) buatlah label serta 5) pembuatan slogan yang menarik untuk produk anda. Guru mengingatkan siswa bahwa barang yang akan dihasilkan adalah benda yang memiliki nilai tambah, dapat dijual dan dikonsumsi oleh orang lain.

\section{Keterampilan berpikir kreatif (Creative Thinking Skills) dan kolaborasi (Collaboration Skills)}

Ketua kelompok membagi tugas individu pada setiap anggotanya yaitu produksi, konsumsi, distribusi, desain label dan membuat slogan produk. Hasil wawancara pada setiap ketua kelompok tanggal 15 maret 2018, menghasilkan kelompok 1 mengolah strawberry menjadi "strawberry milk" dengan tujuan supaya masyarakat dapat menikmati buah strawberry dengan fresh. Kelompok 2 mengolah buah anggur menjadi "kismis anggur" menurut asumsi mereka selama ini masih belum ada yang memproduksinya. Kelompok 3 memproduksi kentang sebagai "donat kentang green tea", dengan destinasi tambahan green tea supaya menarik dan unik. Kelompok 4 mengolah kelapa menjadi "keripik kelapa" selama ini kelapa masih dimanfaatkan sebagai santan, akan lebih menarik jika dimanfaatkan sebagai keripik. Kelompok 5 mengolah jeruk sebagai "sate jeruk caramel", dan memanfaatkan kulit jeruk sebagai "manisan" sehingga kelompok ini menghasilkan dua produk. Kelompok 6 memproduksi manggis sebagai "nastar manggis dan memanfaatkan kulitnya sebagai "obat".

\section{Keterampilan berkomunikasi (Communication Skills) dan kolaborasi (Collaboration Skills)}

Diakhir kegiatan guru meminta siswa untuk melakukan kegiatan karya kunjung ini siswa mampu bertukar informasi, dan menyampaikan gagasan di hadapan siswa lain, terdapat keunikan dalam kegiatan ini yaitu siswa yang berkunjung mereka bersaing melakukan presentasi semenarik mungkin dan memaparkan seunik mungkin dengan gaya mereka masing-masing untuk menarik perhatian. Guru membebaskan siswa untuk mengeksplorasi penyampaian hasil karya mereka dengan gaya masing-masing sebagai wadah mengekspresikan kreativitas siswa. Dalam kegiatan ini diakhiri dengan siswa yang menerima kunjungan memberikan komentar, penilaian dan bintang pada kelompok pengunjung dengan maksimal 5 bintang. Kegiatan pembelajaran ini menghasilkan siswa terampil dalam mengutarakan pandangan, pendapat, dan fakta baru dengan ucapan, karya, lambang, potret, grafis, atau angka.

\section{Implementasi Silent demonstration pada OLEs \\ Pembahasan}

Penerapan silent demonstration menghasilkan siswa lebih tertarik pada demonstrasi guru dan mampu menjaga perhatian tetap fokus dalam pengamatan selama demonstrasi berlangsung. OLEs menyajikan konteks masalah dan menghasilkan masalah untuk ditangani (Externally-induced contexts). Penerapan silent demonstration pada Open Learning Environments (OLEs) menggunakan langkah-langkah terstruktur oleh guru menunjukkan siswa di kelas mudah memahami materi produksi-konsumsi-distribusi sehingga tujuan belajar tercapai.

Silent Demonstration adalah strategi belajar yang menginstruksikan tahap-tahap atau prosedur yang memerlukan konsentrasi siswa sepanjang kegiatan berlangsung 
(Tarigan, 2019). OLEs mendorong siswa untuk berpikir kritis, menggali ide kreatif, mengeksplorasi tanpa batas, menemukan sendiri dan menerapkan belajar yang berbasis heuristic terhadap suatu permasalahan yang tidak terstruktur dan tidak didefinisikan dengan jelas (Hanafin, 1999). Metode silent demonstration selaras dengan kelima prinsip Open Learning Environments (OLEs) yaitu mendorong siswa untuk berpikir kritis, kreatif, dan komunikatif, kolaboratif, mampu berpikir out of the box mengenali masalah serta menemukan solusinya dalam kehidupan nyata juga menyajikan masalah yang bersifat konkret dan otentik (Hannafin et al., 2014)

Model pembelajaran ini mengintegrasikan keterampilan terpadu antara silent demonstration yang menarik perhatian siswa melalui pengamatan dan OLEs yang menyajikan konteks perspektif sumber daya alam dari lingkungan untuk membangun berbagai sudut pandang melalui alat/media sebagai upaya menguatkan pembelajaran $4 \mathrm{C}$ (berpikir kritis, kreatif, kolaboratif dan komunikatif) yang menekankan proses pengetahuan dari pada transfer pengetahuan.

\section{Keterampilan siswa berpikir kritis (Critical Thinking Skills)}

Kegiatan prakondisi Silent Demonstration mendorong siswa berpikir kritis dalam menafsirkan pengamatan, memperhatikan kegiatan demonstrasi kegiatan produksi, konsumsi dan distribusi. OLEs menyajikan konteks perspektif sumber daya alam dari lingkungan kemudian diberikan tantangan tugas dengan memanipulasi kontekstual dan menstimulus siswa berpikir kritis. Tugas dalam pembelajaran ini disajikan berbagai macam gambar buah kemudian siswa diminta untuk menganalisis, memecahkan masalah, mencari solusi, menggali ide-ide kreatif berinteraksi / melakukan diskusikan kemudian menuangkan dalam sebuah temuan baru dalam sebuah karya. Pada kegiatan tersebut memunculkan daya imajinasi siswa untuk menghasilkan sebuah produk, sehingga melalui media tersebut memberikan ruang bagi siswa untuk berfikir kritis untuk kebermanfaatan.

Johnson menjelaskan berpikir kritis adalah kegiatan psikis untuk mendefinisikan masalah, menemukan solusi, memahami peristiwa tertentu, dan menemukan jawaban yang relevan (Johnson, 2002). Enis dan Marzano et al. mengemukakan pendekatan yang mengasah berpikir kritis adalah pembelajaran berpusat pada siswa, peka terhadap masalahmasalah kontekstual di kehidupan nyata (Costa, 2001; Marzano, 1988). Arends dalam John Santrock mengemukakan, strategi yang mampu melatih siswa dalam pemecahan masalah adalah problem based learning, project based learning, cooperatif group investigation, inquiry learning dan lainnya (John W. Santrock, 2011). Menurut Hannafin dalam Reigeluth (1999) tujuan prakondisi OLEs untuk mendorong berpikir kritis, pembelajaran yang berorientasi pada inquiry-oriented dan heuristic-based learning, secara mandiri yang tidak diarahkan dan tidak terstruktur (Hannafin et al., 2014).

Keterampilan berpikir kritis ini sangat diperlukan dalam menghadapi persoalan dan menarik keputusan dalam kehidupan nyata. Keterampilan ini dapat dilatihkan dalam pembelajaran dengan memberikan tantangan siswa melalui sajian kasus-kasus nyata setiap hari. OLEs menghadapkan siswa dengan masalah yang harus mereka selidiki dari berbagai perspektif untuk memberikan jalan keluar yang tepat. Pertimbangan berbagai sudut pandang siswa mampu merangsang fleksibilitas kognitif siswa.

\section{Keterampilan berpikir kreatif (Creative Thinking Skills)}

Dalam kegiatan ini siswa kelas VIII $\mathrm{G}$ dan VIII $\mathrm{H}$ melalui imajinasi mampu menciptakan ide atau gagasan aktual dari yang sebelumnya dengan menambahkan inovasi. Berpikir kreatif dalam kegiatan ini siswa disajikan bermacam gambar buah diberikan 
waktu untuk berimajinasi, berkreasi serta mengolahnya menjadi barang barang yang lebih bermanfaat, memiliki nilai jual dan unik. Guru tidak memberikan prosedur atau langkahlangkah dan petunjuk terstruktur apa yang harus dilakukan siswa. Dalam kegiatan ini siswa diberikan kesempatan seluas-luasnya untuk memberikan pemecahan masalah dari sudut pandang dan pengetahuan mereka. Guru membebaskan siswa mengeksplorasi sehingga dapat menciptakan sesuatu gagasan berlainan lebih dahulu.

Berpikir kreatif adalah kemahiran menguraikan ide yang antik, bermutu, dan sesuai karakter (Sani, 2014) menginspirasi siswa melalui bertukar pengalaman dan manfaat berbagai ide (G U O, 2016) penguasaan memperoleh pemikiran baru (Piawa, 2010) membuat dan menghasilkan pemikiran serta pengalaman lama dan baru (Hotaman, 2008) membentuk rancangan baru, melengkapi produk yang ada melibatkan unsur-unsur orisinalitas, kelancaran, fleksibilitas, dan elaborasi (NEA Association, 2012).

Kreativitas merupakan kecakapan yang berpengaruh dan sentral pembelajaran efektif pada abad 21. Dalam kegiatan ini siswa mampu lentur (flexibility) memandang masalah dari berbagai perspektif, jalan keluar pemecahan masalah secara bervariasi. Hal ini sesuai dengan salah satu prinsip OLEs dimana guru membebaskan siswa membangun sudut pandang yang berbeda sehingga mampu menghasilkan suatu gagasan baru. Keaslian (originality) dalam daya cipta adalah hasil kreativitas personal yang istimewa dan jarang dimiliki orang lain.

\section{Keterampilan berkomunikasi (Communication Skills)}

Hasil penelitian ini siswa mampu menyampaikan argumen, gagasan, pemikiran dan mendengarkan saran teman dalam kelompok dengan baik. Selama kegiatan pembelajaran berlangsung, siswa mampu mendengarkan pendapat teman yang lain, dapat berinteraksi dan mengambil keputusan bersama. Dalam kegiatan penutup semua kelompok melakukan karya kunjung, dimana 2 siswa setiap kelompok melakukan kunjungan ke kelompok lain dengan mempresentasikan karya mereka selama 3 menit dan 3 siswa menerima tamu kunjungan untuk melakukan tanya jawab selama 5 menit. Pada kegiatan ini walaupun dalam waktu yang singkat dalam kegiatan presentasi dan tanya jawab dapat memberikan ruang bagi siswa dalam meningkatkan keterampilan berbicara.

Komunikasi merupakan kecakapan yang mengikutsertakan, pengamatan, menjelaskan, menanya, mendengar, menganalisis serta mengevaluasi makna melalui media (Partnership for 21st Century Learning, 2015). Komunikasi merupakan kecakapan perseorangan dalam berhubungan dengan ucapan atau tercatat, dan bekerjasama secara efektif (Center, 2010) menyampaikan pandangan, inspirasi, wawasan yang aktual secara tercatat maupun ucapan (NEA Association, 2012).

Komunikasi merupakan hal terpenting bagi manusia dalam berinteraksi di masyarakat sebagai makhluk sosial. Dalam kegiatan pembelajaran ini siswa melakukan diskusi, komunikasi hingga mencapai kesepakatan bersama dalam kelompok secara verbal maupun nonverbal. Siswa mampu memahami makna nilai, sikap dan budaya, dari teman kelompok, memanfaatkan media, serta mampu berkomunikasi pada lingkungan.

\section{Keterampilan kolaborasi (Collaboration Skills)}

Pada kegiatan pembelajaran siswa mampu bekerjasama dalam kelompok, menyepakati produk yang akan dibuat, melakukan pembagian tugas masing-masing siswa dalam kelompok bagian produksi, konsumsi, distribusi, menggambar label dan membuat slogan untuk proyek yang mereka kerjakan. Saling memotivasi dan bersinergi, berbagi 
peran dan tanggung jawab pada masing-masing siswa. Siswa juga mampu menghormati perbedaan pendapat yang ada dalam kelompok serta mendapatkan solusi.

Kerjasama yaitu kecakapan dalam menguraikan daya intelektual secara bersama dalam mengakomodasi, dan menyepakati melalui interaksi (Brown, 2015) bekerja dengan luwes, efisien, dan mengakhiri tugas secara kolektif (NEA Association, 2012; Partnership for 21st Century Learning, 2015). Tiga unsur berkolaborasi yaitu: kecakapan dalam berkarya dan menghargai kemajemukan tim, luwes menerima pendapat orang lain, menjalankan kewajiban bersama dan menghargai peran serta tim (Tican \& Deniz, 2018).

\section{KESIMPULAN}

Kesimpulan diambil berdasarkan hasil penelitian dan pembahasan, maka dapat disimpulkan bahwa implementasi silent demonstration pada OLEs menarik perhatian siswa melalui pengamatan dalam memahami kegiatan produksi, konsumsi dan distribusi sehingga tujuan pembelajaran tercapai. Kegiatan pembelajaran ini mengintegrasikan keterampilan terpadu antara Silent Demonstration yang menarik perhatian siswa melalui pengamatan dan Open Learning Environments (OLEs) yang menyajikan konteks perspektif sumber daya alam dari lingkungan untuk membangun berbagai sudut pandang melalui alat/media sebagai upaya menguatkan pembelajaran 4C (berpikir kritis, kreatif, kolaboratif dan komunikatif).

\section{DAFTAR PUSTAKA}

Akgunduz, Y. (2015). The influence of self-esteem and role stress on job performance in hotel businesses. International Journal of Contemporary Hospitality Management. https://doi.org/10.1108/IJCHM-09-2013-0421

Asari, A. R., Malang, U. N., \& Timur, J. (2015). Untuk Meningkatkan Daya Saing Siswa Indonesia. September. https://doi.org/10.13140/RG.2.1.2687.2804

Brown, B. (2015). Twenty first century skills: A bermuda college perspective. Voices in Education Student Success: A National Focus, 1, 58-68.

Center, P. P. R. (2010). 21st Century Skills for Students and Teachers. Honolulu: Kamehameha Schools. Research \& Evaluation Division. Research \& Evaluation Division.

Charles M.Reigeluth Alison A.Carr-Chellman. (1389). Instructional-Design Theories and Models Building a Common Knowledge Base (Vol. 1, Issue 4).

Costa, A. L. (2001). Developing minds: A resource book for teaching thinking. ERIC.

Creswell, J. W. (2015). Penelitian kualitatif \& desain riset: memilih diantara lima pendekatan. Yogyakarta: Pustaka Pelajar.

G U O, Z. (2016). The cultivation of 4C's in China-Critical thinking, communication, collaboration and creativity. DEStech Transactions on Social Science, Education and Human Science, emass.

Ghony, D. (2012). Fauzan, Metodologi Penelitian Kualitatif. Jakarta: Ar-ruzz Media. 
Gulo, M., \& Tamba, L. (2019). Pengaruh Model Pembelajaran Silent Demonstration Terhadap Kemampuan Menulis Teks Prosedur Siswa kelas VIII SMP Budi Murni 3 Medan. Jurnal Pendidikan Bahasa Indonesia Dan Sastra (Pendistra), 2(1), 46-55.

Hanafin, M. (1999). Open Learning Environment: Foundation, Methods, and Models. Instructional Designing Theories and Model: A New Paradigm of Instructional Theory, vol. II. Lawrence Erlbaum Associates, Mahlway.

Hannafin, M. J., Hill, J. R., Land, S. M., \& Lee, E. (2014). Student-centered, open learning environments: Research, theory, and practice. In Handbook of research on educational communications and technology (pp. 641-651). Springer.

Herawati, A. I. (2016). Pengaruh Strategi Silent Demonstration (Demonstrasi Bisu) Terhadap Minat Belajar Siswa Kelas V Pada Mata Pelajaran IPA Di MI Daarul Aitam Palembang.[Skripsi]. Uin Raden Fatah Palembang.

Hidayatullah, Z., Wilujeng, I., Nurhasanah, N., Gusemanto, T. G., \& Makhrus, M. (2021). Synthesis of the 21st Century Skills (4C) Based Physics Education Research In Indonesia. JIPF (Jurnal Ilmu Pendidikan Fisika), 6(1), 88. https://doi.org/10.26737/jipf.v6i1.1889

Hotaman, D. (2008). The Examination of the Basic Skill Levels of the Students in Accordance with the Perceptions of Teachers, Parents and Students. Online Submission, 1(2), 39-55.

John W. Santrock. (2011). Educational Psychology (Michael Ryan (ed.); 5th ed.). Michael Sugarman.

Johnson, E. B. (2002). Contextual teaching and learning: What it is and why it's here to stay. Corwin Press.

Marzano, R. J. (1988). Dimensions of thinking: A framework for curriculum and instruction. ERIC.

Moleong, L. J. (2019). Metodologi penelitian kualitatif.

Nazir, M. (1988). MetodePenelitian. Jakarta: Ghalia Indonesia.

NEA Association, N. E. (2012). Preparing 21st century students for a global society: An educator's guide to" the four Cs." Washington, DC.

Nurhemy, T. N., Santosa, S., \& Probosari, R. M. (2011). Penerapan Active Learning Dengan Silent Demonstration Untuk Meningkatkan Keterampilan Proses Sains Siswa Kelas VIII D SMP Negeri 14surakarta. Pendidikan Biologi, 3(3).

Partnership for 21st Century Learning. (2015). P21 framework definitions. Washington, $D C$.

Piawa, C. Y. (2010). Building a test to assess creative and critical thinking simultaneously. 
Procedia-Social and Behavioral Sciences, 2(2), 551-559.

Sani, R. A. (2014). Pembelajaran saintifik untuk implementasi kurikulum 2013. bumi aksara.

Tarigan, S. A. (2019). Pengaruh Metode Silent Demonstration Terhadap Kemampuan Memperagakan Teks Prosedur Siswa Kelas VII SMP Negeri 13 Medan Tahun Pembelajaran 2019/2020.

Tican, C., \& Deniz, S. (2018). European Journal of Educational Research. 8(1), 181-197. https://doi.org/10.12973/eu-jer.8.1.181

Zubaidah, S. (2018). Mengenal 4C: Learning And Innovation Skills Untuk Menghadapi. 2nd Science Education National Conference. Bangkalan: Universitas Trunojoyo. 